\title{
Science and Technology Policies and the Middle Income Trap: Lessons from Vietnam
}

\begin{abstract}
As Vietnam crossed the World Bank's threshold from 'low income' to 'lower middle-income' in 2010 the government and aid donors started to speak about 'the middle income trap' as a central problem; and to frame 'science and technology (S\&T) policy' as a means of sustaining economic growth and thereby avoiding the trap. They identified China and its Made in China 2025 programme as a model, and pointed to Intel's \$1 billion facility as evidence of a burgeoning technology hub. Yet in the years that followed, Vietnam's S\&T policy has limped along, with efforts simply to boost the number of Silicon Valley-styled start-ups. This paper reveals two main reasons. First, the Ministry of Science and Technology is a weak ministry with little budget, unable to persuade other ministries to cooperate in more ambitious and capital-intensive strategies. Second, excitement around S\&T policies was fuelled by an influx of high-tech Vietnamese returning home after the 2008 Global Financial Crisis, lending support for building start-up ecosystems. These mechanisms are reinforced by western aid agencies support for this narrow S\&T policy conception. Findings are based on policy documents and interviews conducted with S\&T policymakers, aid donor staff, and start-up investors between 2012 and 2018.
\end{abstract}

\section{Introduction}

Vietnam has been held up in development circles since the early 2000s as an emerging East Asian tiger, fast moving up in income and technology. Intel's opening of its biggest chip making plant outside the US in 2010 seemed to confirm it as an emerging information and communication technology (ICT) hub. Other major western, Japanese and Korean multi-national corporations (MNCs), such as Samsung, Fujitsu and Toshiba, also established production operations in the country.

But knowledgeable commentators, Vietnamese and foreign, argued that this momentum could not be sustained without a sizable increase in the role of government in pushing investment in science and technology (S\&T), including in a big expansion of science and engineering education and in the budgets of public and private laboratories. This concern came to a head when, in 2010, Vietnam officially crossed from low-income to lower middle income status by the World Bank threshold. The event prompted an upsurge of discussion from policymakers and 
the donor community about the need for the Socialist Republic to rapidly upgrade, modernise and industrialise production. Otherwise, the middle income trap loomed (Ohno, 2009).

A 2010 World Bank report about Vietnam warned that the 'middle-income trap does not set in only when countries reach the high end of the middle-income range. Countries can be stuck in a low-growth trajectory even at low levels of income' (Cheong, Duc \& Nguyen, 2010, p. 32). The following year another Bank report advocated that Vietnam shift to 'higher productivity, product and process innovation and value addition as its low-cost labour advantage begins to dissipate' (World Bank, 2011, p. i). Within the government, the Ministry of Planning and Investment (MPI) and Ministry of Science and Technology (MoST), have echoed this discourse, warning that the government must help to lead the composition of investment, and not just create optimal conditions for exchange, in order to reduce the chances of getting stuck on a low or volatile growth trajectory as costs and incomes rise. The widely publicised Vietnam 2035 , published in February 2016, recommends that the government 'strengthen' and 'coordinate' its S\&T system as a priority to 'avoid falling into the middle income trap and lagging behind'. In November 2018, Chu Ngoc Anh, the Minister of Science and Technology, stated that 'Vietnam needs to develop a national strategy’ (Akhaya, 2018).

The middle income trap hypothesis says that countries in the middle income range are likely to experience a flattening of their decadal economic growth rates as productive capabilities lag behind rising costs of production (Gill \& Kharas, 2007; Doner \& Schneider, 2016). According to Masina (2010, p. 14): no 'ASEAN country [including Vietnam] has been able to break through the invisible "glass ceiling" between the existing national system with a supporting industry still dependent on foreign guidance and a national system in which management and technology have been internalised and mastered.' 
For Vietnam to break through the 'glass ceiling', the consensus identified a bold increase in S\&T promotion as a vital ingredient, as part of a larger Socialist Market Economy growth plan. Policymakers drew inspiration from China's remarkable S\&T advance, in particular its missionshaped policy initiatives such as Made in China 2025, which aims to catapult the country to world leadership in artificial intelligence, robotics, and other frontier technologies (Lee, 2018). Such mission-oriented innovation policies articulate big ambitions beyond tactical goals for a particular policy - the US government's mission to put a man on the moon is a classic example - (see Breznitz, Ornston \& Samford, 2018; Mazzucato, 2018). Vietnamese policymakers observed China's exceptional growth and S\&T advances in an institutional context of decentralised policymaking with objectives set by central government bodies and implementation left to provincial government, and said, 'We should be able to do the same' (Lewin, Kenney \& Murmann, 2016).

But in the nearly 10 years since reaching lower middle-income status, by most measures Vietnam has not implemented a mission-oriented, substantially-funded S\&T policy that would help it overhaul its national system of innovation (NIS) in order to shift from simple imitation, assembly and testing into indigenous innovation. Rather, the government's efforts have been limited to growing what it calls Vietnam's Silicon Valley -- multiplying the number and size of high-tech startups, of whatever kind. The Prime Minister 'now has startups at the top of the agenda' (personal communication, November 29, 2018). The aim is to have 5,000 startups up and running by 2025 , according to Plan 844 , regardless of sector or technological capacity. This is a long way short of the Chinese government's 'strong, interventionist approach in an attempt to promote specific kinds of technology transfer and spillovers' (Collinson, 2016, p. 225). 
This paper examines the gap between the rhetoric of emulating China's state efforts for promoting innovation and the reality of little public investment in R\&D. We explore what has actually happened by way of S\&T strategy in Vietnam, and in particular, to what extent it has copied China's approach. We analyse (1) the extent to which Vietnam's S\&T policy has precise missions, (2) the degree to which the government is promoting technical innovations through public R\&D spending or offering incentives for private $R \& D$, and (3) the extent to which the national innovation system is being reformed to grow the number of startups. We find that the only significant change to Vietnam's S\&T policy is in the third type of S\&T policies, focused on promoting the volume - though not also the technical capacity - of startups.

We then explain that the Silicon Valley-nature of Vietnam's S\&T policy is primarily the result of the confluence of two factors. First, the Ministry of Science and Technology (MoST) is a relatively weak ministry, which is allocated a small budget from the much more powerful Ministry of Planning and Investment (MPI). Aware of their limited access to budget and the challenges of implementing policies even when they obtain budget commitments, MoST policymakers have an aversion to pursuing capital-intensive, bureaucratically-complex initiatives, including of the mission type. Policies to promote a Silicon Valley-style entrepreneurial ecosystem require little money, and the accelerator programmes, events and competitions are administered through public-private partnerships, making them easier to run. This makes 'startup ecosystem building' policies an attractive alternative to sizeable S\&T spending for specific technical capacity building.

Second, MoST policymakers' proclivity for light-touch policy strategies resonates with the preferences of the large number of high-tech Vietnamese who left the United States after the Global Financial Crisis to return home to pursue growing opportunities (Peel, 2015). These well- 
placed returnees have advocated for government support for accelerator initiatives, venture capital funding and exchanges, in some cases offering to lead the efforts. These mechanisms are reinforced by western aid donors who are funding startup ecosystem building programmes aimed simply at increasing the number of firms.

Our findings are based on an analysis of the content of Vietnam's S\&T policy over time, in particular in the period since 2010 when policymakers explicitly linked S\&T to escaping the middle income trap. We use both documents and material from primary interviews conducted between 2012 and 2018 with government officials in the MoST, the National Agency for Technology Entrepreneurship and Commercialisation Development (NATEC), the Vietnam Silicon Valley Project, the MPI's Agency for SME Development, and finally, the World Bank Vietnam country team in Hanoi. While other papers in this special issue focus on firm capabilities, we account for the gap between the rhetoric and the reality of S\&T policy. The gap means that firms' innovation capabilities are being raised more slowly than the speechmaking would suggest.

The article contributes to development studies by drawing together the literatures about S\&T policy, the middle income trap and the political economy of Vietnam. After this introduction, section II describes the three types of S\&T policy. Section III outlines the trajectory of Vietnam's S\&T policies from the 1980s. Then in section IV we examine the context for S\&T policies by exploring Vietnam's ICT activities, including the capabilities of startups and the relationship between the MNCs and local firms. Section V explains the mismatch between rhetoric and reality, drawing on fieldwork insights. Section VI closes by discussing, more broadly, how the middle income trap discourse has been used in Vietnam to justify growing the 
volume of entrepreneurship, without catalysing significant actions for upgrading specific firm innovation capabilities.

\section{S\&T policy for escaping the middle income trap}

S\&T policy is commonly understood as a major component of the larger category of 'innovation policy'. Innovation policies are those that strive to advance 'new combinations', to use Schumpeter's phrase (1934). Edler and Fagerberg (2017, p. 5) explain that innovation policy, as a term, became popular only from the mid-1990s, and much of what is now called innovation policy was previously labelled as 'industrial policy, science policy, research policy, or technology policy.'

In Vietnam there are some policies that employ the language of innovation, such as the $€ 11$ million Finland-Vietnam Innovation Partnership Programme and the $\$ 47$ million National Technology Innovation Fund launched in 2015. But the majority of policymaking still employs the S\&T nomenclature. Notably, in 2013, the government articulated science, technology and related terms in the encompassing Law on Science and Technology (No. 29/2013/QH13). For this reason, in this article we use the language of S\&T policy when speaking about Vietnam, rather than the more generic label of innovation policy.

In the general literature about science, technology and innovation policies, there are numerous classifications according to the intention of the policy and the instruments used (see, for example, Nee \& Opper, 2012; Klingler-Vidra, 2014a; Child, 2016). One 
common classification is tri-partite: policies are either 'mission-oriented', 'inventionoriented' or 'system-oriented' (Edler and Faberberg, 2017).

'Mission-oriented' policy targets a big societal outcome, such as 'man on the moon', and so goes beyond specific aims of increasing available funding, the number of firms, and so forth (Ergas, 1986; Breznitz, Ornston \& Samford, 2018; Mazzucato, 2018). Mission-oriented policies are also conceptualised as 'innovation from above' (Nee \& Opper, 2012). Made in China 2025 is a contemporary example of mission-oriented policy: the policy package cites the ambitious mission of China becoming the worldleader in artificial intelligence and other frontier technologies (Lee, 2018). A number of specific, sector vertical policies - often referred to as 'industrial policy' - underpin this grand ambition. Industrial policies are 'directive' policies that 'select sectors, regions, and specific categories of innovation as targets' (Child, 2016, p. 207), whereas mission oriented policies articulate a bigger goal than whatever particular sector or category the policies affect.

The second category of policies are 'invention policies' that focus narrowly on the invention phase, rather than the 'possible exploitation and diffusion of the invention to market' (Edler \& Faberberg, 2017, p. 5). This policy type emphasises investment in R\&D - whether conducted by state, university and business - in almost any sector. It is perhaps the closest analogue to what has historically been referred to as S\&T policy; focusing on invention capacity rather than commercialisation. Within this type, policies take the form of government $R \& D$ expenditure, subsidies to encourage private $R \& D$ spending, the staffing of public research organisations, and perhaps public funding for education in science and engineering. Public support for R\& D is typically justified by 
the presumption that there is an acute market failure in private sector firms investing in R\&D due to its 'public good' nature, as knowledge 'spills over' to the public. The worry for potential investors in $R \& D$ is that they will bear the costs, but then too much of the benefit may accrue to others, meaning that the investment is not worthwhile for them (Hall, 2002; Huergo \& Moreno, 2017).

The third type of policy aims to strengthen system-level capabilities of the kind known in the literature as the national innovation system (NIS). The NIS encompasses technology commercialisation and firm promotion (see Lundvall, 1992; OECD, 1997; Nelson, 1988; Niosi, 2008). Increasingly in the post-Global Financial Crisis era, NIS policies support ecosystems for new innovative business ventures, ranging from changes in national curriculum in which basic computer programming is taught in primary school through to regulations that make it easier for startup founder to declare bankruptcy. NIS policies can also encourage activities through soft power forms such as running a national version of 'Dragon's Den' or 'Shark Tank' to normalise entrepreneurial activities. The focus of NIS policies on Silicon Valley-like startup clusters stems from the assumption that new firms are said to expand 'the technology frontier because they tend to engage in more radical innovations', whereas (so the theory goes) incumbent firms are expected to focus on incremental product and process innovations (Autio \& Ranniko, 2016; Fuller, 2010; IMF, 2016, p. 39; Lerner, 2009; OECD, 2007; Warwick \& Nolan, 2014).

\section{Vietnam's S\&T policy}


If the government - particularly the MoST - acted in accordance with statements of commitment to S\&T capability building made since 2010, we would expect to see: (a) the rise of mission-oriented policies, (b) an increase in invention promotion by either public investment in $\mathrm{R} \& \mathrm{D}$ or tax incentives for private $\mathrm{R} \& \mathrm{D}$, and (c) an overhaul of the NIS favouring startup activities. This section shows that next-to-nothing has been done in line with the first form. No major 'up-towards-the-best in the world' missions have been articulated. The state's R\&D spending has been stubbornly static, though there have been further extensions of tax incentives for private R\&D; so some movement on policy type two. The most significant change has come in the third category, which takes the form of rising emphasis on Silicon Valley-inspired SME ecosystem development.

In this section we describe the trajectory of Vietnam's S\&T policies starting in 1981. This was a watershed year in Vietnam's S\&T policy as it marks the government's removal of its monopoly on R\&D such that private firms could sign R\&D contracts with individuals and private organisations. Table 1 below illustrates how policy and institutional attempts to stimulate technology upgrading were made over time. Notice that the emphasis throughout has been on policies to promote 'marketisation', which simply aim to increase the number of firms, as distinct from formulating advance in specific directions.

Table 1: Key Science \& Technology Policy (1981-2018)

- 1981: Decision 175 allows the (private) signing of R\&D contracts.

- 1987: Decision 134 encourages science and technology.

- 1988: Ordinance on Foreign Technology Transfer provides for implementation of the 1987 Law on Foreign Investment.

- 1992: Decree 35 allows the establishment of non-state R\&D organisations.

- 1993: National Centre for Scientific Research renamed the National Centre for Natural Science and Technology, with the aim of conducting fundamental and applied research. 
- 1996: Resolution 2 names S\&T development strategy as part of industrialisation and modernisation mission.

- 1999: Decree 119 sets the legal basis for public support for S\&T firms.

- 2000: First Law on S\&T; Decision 850 creates national laboratories.

- 2003: Announcement that the first S\&T Development Strategy will be set by 2010 and The National Foundation for Science and Technology Development (NAFOSTED) is founded.

- 2005: Decision 214 on the 'development of technology market'.

- 2006: Law on technology transfer and Prime Minister Decree 80 on commercialisation.

- 2007: Creation of the State Agency for Technology and Innovation (SATI) and the National Council for Science and Technology Policy to advise the Prime Minister.

- 2008: High-technology Law passed; NAFOSTED and the Science and Technology Fund launch operations.

- 2011: Plan to foster international integration in S\&T and Creation of the National Agency for Technology Entrepreneurship and Commercialisation Development (NATEC).

- 2012: Prime Minister approves the 2011-2020 Science and Technology Development Strategy and Decision No. 592 sets aim of 3,000 S\&T SMEs by 2015 and 5,000 by 2020.

- 2013: S\&T Law recognises S\&T enterprises for incentives and R\&D access; Central Resolution 6 advocates development of S\&T in the context of a Socialist-oriented market economy and international integration; MoST initiates Vietnam Silicon Valley Project.

- 2015: TechFest Vietnam, an annual event for the startup ecosystem, and the National Technology Innovation Fund, both launched by MoST.

- 2016: Prime Minister Decision 844 to support the national startup ecosystem to 2025.

- 2017: SME Support Law offers tax incentives, credit access and accounting support.

- 2018: The Law on Supporting Small and Medium-Sized Enterprises and Decree 38, on innovative startup investments, came into effect.

Source: Authors adapted from Vu, Hong \& Hoang (2010), Klingler-Vidra (2014b), OECD (2011), OECD/World Bank (2014, pp. 179-182), CIEM, GSO \& Department of Economics (2015), $\operatorname{MoST}(2015,2016)$, MPI AED (2016), Das (2018).

Efforts were stepped up in 1996, when 'Science and Technology' was first named as a priority sector for speeding up industrialisation and modernisation. Policymakers said that they aimed to develop a hardware and a software industry for the nation. In 2000, a high-level directive (58-CT/TW) named S\&T 'application and development' critical to national industrialisation and modernisation. Then in 2003 the government announced its intention to complete the first S\&T development strategy by 2010.

This brand of marketisation policy continued after crossing the middle income threshold.

The country's 2011-2015 plan stated the intention to support science and technology in order to 
generally be 'highly competitive and better linked with global markets' (World Bank, 2012, p. 43). For example, in 2011 the government approved the national technological renewal programme through 2020, which identified the MoST's goal as the training of ' 80,000 engineers, technicians and managers who are employed in SMEs' (Hue, 2017, p. 2). Another such decision at the same time approved 'the plan for developing medium and small enterprises', to be headed by the Ministry of Industry and Trade. This plan takes an emphatically broad tack, with its 'national industrial encouragement programme' aiming to mobilise domestic and overseas resources to participate in industrial production and services in rural areas to 'develop industry there at the same speed as the whole country' (Decision No. 1231/QD-TTg).

National S\&T strategies, including those for 2011-15 and 2016-20, do name some priority sectors for development, such as information and communications technology, biotech, new material and automatic technologies. But interviewees said consistently that statements of such aims were not backed up with policy action. When asked about the focus of S\&T policy, a member of the S\&T policy team at the World Bank in Vietnam remarked that 'Vietnam does not have a coherent science and technology strategy, and then strategies are not backed up by feasible action plans' (personal communication, October 27, 2016). A startup investor made a similar assessment, commenting that 'the government just gives money to young people wanting to be entrepreneurs without giving them specific mentoring and skills training' (personal communication, August 24, 2012).

Government budget trends reveal the rather low priority attached - in practice - to boosting S\&T capabilities. The share of the state budget spent for S\&T, which includes public spending on R\&D, high-tech parks, venture capital funds, and more, has remained flat. Not only 
is it far below the mandated target of two per cent, it has not even returned to the previous high of 1.9 per cent reached in 2007, as illustrated in Figure 1.

Figure 1: Government S\&T expenditure as a per cent of state budget

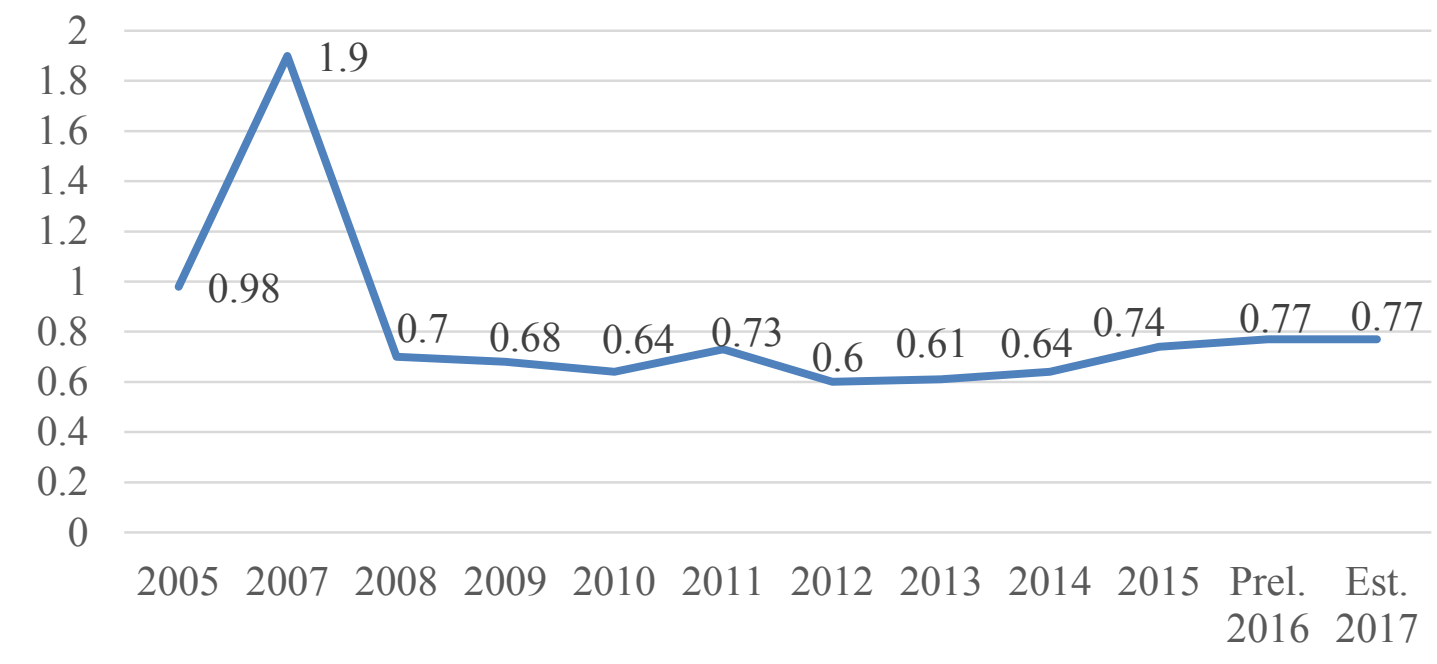

Source: Authors' analysis based upon data from the General Statistics Office of Vietnam

In an interview, a National Agency for Technology Entrepreneurship and Commercialisation Development manager explained that S\&T spending across the MoST, other ministries and provincial governments is approximately ' 745 mil USD per year.' She went on to explain that although it's stipulated in the S\&T Law that every year two per cent of government spending will be allocated for S\&T, 'in reality it's always much less than that because a big chunk is used for Military spending' (personal communication, December 28, 2016). Another interviewee further explained that the Ministry of Defence is a powerful government ministry, and is able to secure a large amount of the money otherwise earmarked for S\&T, whereas 'the MoST does not have power, and so does not get budget' (personal communication, November 29, 2019). Thus, not 
even all of the low proportion of the state budget spent on S\&T ( 0.77 per cent $)$ is actually spent on promoting science and technology.

Similar to the slow growth of public S\&T expenditure, the share of total R\&D spending in GDP - collectively, by government, businesses and universities - has barely grown over the last decade. The government's aim to more than double R\&D spending between 2010 and 2020, to 1.5 per cent of GDP, remains far from the reality of gross expenditure on R\&D of 0.4 per cent of GDP. Whilst the modest R\&D spending level may be partly explained by the country's still low average income, the trajectory of its $R \& D$ intensity remains well below that of China and ASEAN peers. In the same period, Malaysia has seen marked R\&D growth while Thailand's R\&D spending also outpaces Vietnam, as illustrated in Figure 2 below.

Figure 2: R\&D intensity (share of GDP): Vietnam, Thailand, Malaysia and China 2002-2015

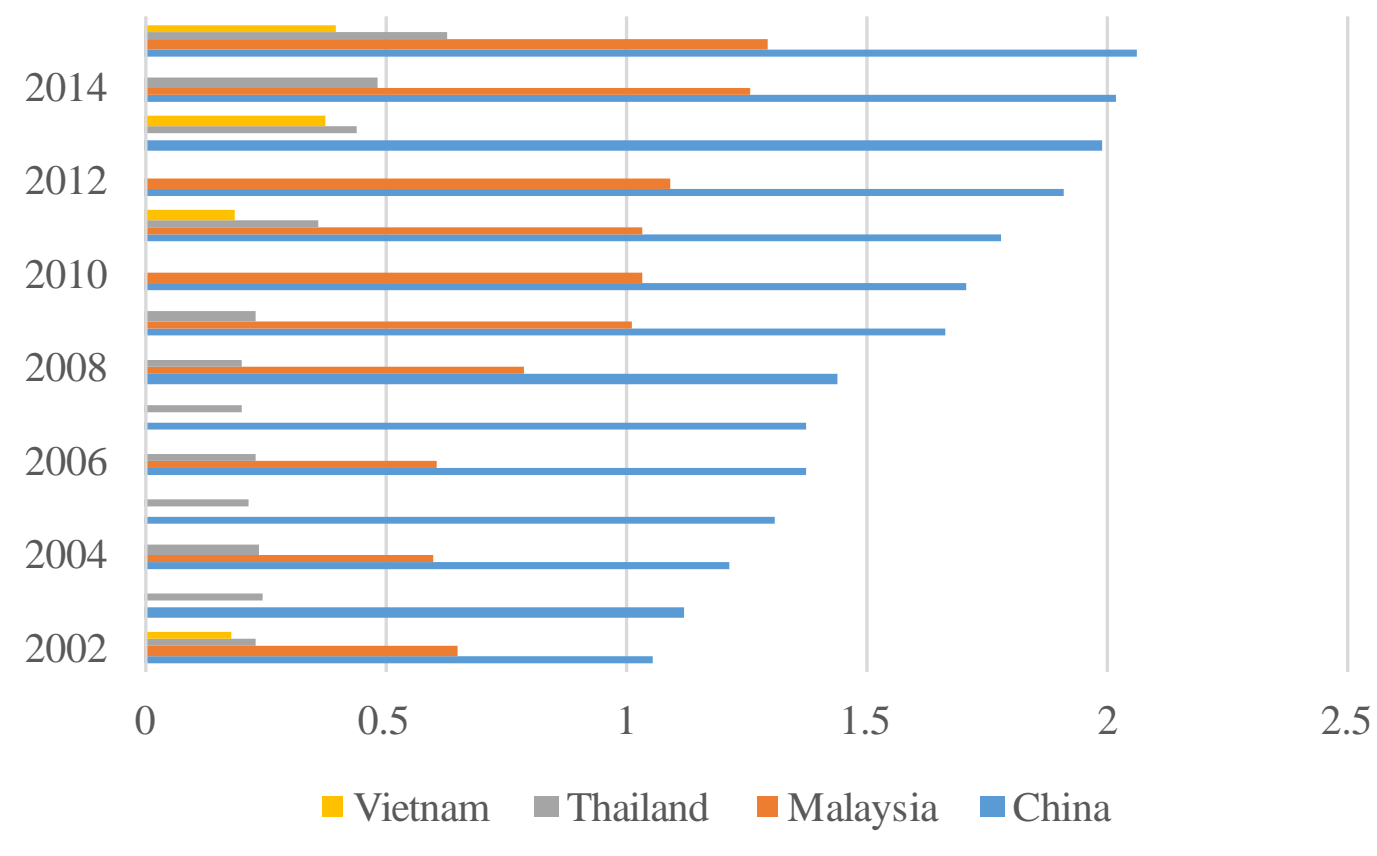

Source: Author analysis of World Bank data 
The low growth of total $R \& D$ spending results from the very low growth of public spending on $R \& D$. But strangely, figures for government spending on $R \& D$ are not published, and our statement about 'very low growth of public spending on R\&D' is derived from interviews with insiders. A 2014 interview with the Minister of Science and Technology, Nguyen Quan, revealed that only about 10 per cent of annual public S\&T spending goes towards R\&D (VietnamNet, 2014).

Instead of ramping up government $R \& D$ investment as China has, the government has incentivised private sector R\&D spending through the 2013 S\&T Law. This includes non-state enterprises' ability to allocate up to 10 per cent of taxable income for an enterprise-level S\&T development fund (MoST, 2014, p. 40). The private tax incentives for R\&D spending appear to be bearing fruit as, according to UNESCO Institute for Statistics data, business expenditure on $R \& D$ grew from 26 per cent of gross expenditure on $R \& D$ in 2011 to 64 per cent in 2015 . We should note that this growth is based upon firms' accounting, so - with tax incentives at stake we cannot be assured of accuracy.

The government's main priority - in practice - has been on encouraging a NIS that supports an increasing number of startups. The first major agency to be created in the wake of crossing the income threshold was the National Agency for Technology Entrepreneurship and Commercialisation Development (NATEC) in 2011. The role of NATEC is to advise the MPI, MoF, MoST, the Prime Minister's office and provincial governments on 'carrying out management functions for developing the technology market and in supporting the establishment of S\&T enterprises' (SEA-EU-NET, 2018). The NATEC team is comprised of ' 35 official long-term employees and 30 contracted' and runs on 'administrative costs of about $\$ 130,000$ ' (personal communication, 
December 28, 2016). The lean NATEC team is charged with the aim of promoting innovative entrepreneurial ecosystems across Vietnam by working with multiple government divisions.

Then in 2013 the MoST created what has become its flagship startup ecosystem programme, the Vietnam Silicon Valley Project, which runs accelerators for investors and entrepreneurs. Its aim is to 'build a Silicon Valley for Startups in Vietnam.' The ambition is grand, but the budget is small, starting with only $\$ 400,000$ in June 2013 . What is more, most of that small budget came not from MoST, but from the project's private founder, "with the government then only coming in a year later to offer match funding and free office space' (personal communication, November 29, 2018). Since then, it has run accelerator programmes for as brief as a weekend for angel investors, to up to four months long for entrepreneurs, in partnership with corporate partners including Microsoft, Lotte, Vietnam International Bank, academic institutions (Foreign Trade University) and local government such as the Ho Chi Minh City Department of Science and Technology. In addition, the Vietnam Silicon Valley Project acts as a coordinator for entrepreneurship promotion within the MoST, as it is a co-organiser of TechFest, the annual startup conference and exhibition, and responsible for running the Vietnam Silicon Valley (VSV) Corner, a physical hub for startups opened in 2015 in Hanoi's Hoan Kiem district.

Shortly after the release of the Vietnam 2035 report, in May 2016, government resolution 35 identified further objectives for supporting innovative startups. The aims include the targets of creating 5,000 S\&T-focused SMEs and 30 high-tech technology and enterprise incubators between 2016 and 2020. Like the earlier- mentioned target set 
in 2011 of training 80,000 engineers, technicians and managers of SMEs by 2020, these figures are plucked from the air, lacking any discernible analytical underpinnings.

One particular programme deserves attention. Known as Project 844 based on Decision 844/QD-TTg/2016, 'Supporting National Innovative Startup Ecosystem to $2025^{\prime}$, it bolsters the innovation ecosystem by providing funding to 200 startups, developing a startup friendly legal system and creating a collaborative online platform for startups. The portal is the lynchpin of the Vietnam Silicon Valley Project, to bring the various members of the ecosystem - entrepreneurs, investors, researchers, policymakers and foreigner firms and investors - together. As one interviewee remarked, it is about increasing 'exchange' rather than technical skills (personal communication, 14 October 2016). The effort is led by the MoST in collaboration with provincial governments (Departments of Science and Technology) and ecosystem stakeholders on the steering committee, including venture capital firms (Cyberagent Ventures), FPT Corporation, Vietnam Silicon Valley and Topica Founder Institute (the World Bank-funded accelerator in Ho Chi Minh City).

Table 2 below offers a summary of the marquee S\&T policies - according to the three types identified earlier - implemented between 2010 and 2018, comparing Vietnam's policies with China's S\&T policy in the same period.

Table 2: Overview of China and Vietnam S\&T policymaking 2010-2018

\begin{tabular}{|l|l|l|}
\hline & China & Vietnam \\
\hline Mission-oriented policies \\
\hline
\end{tabular}




\begin{tabular}{|c|c|c|}
\hline $\begin{array}{l}\text { Key S\&T programmes and } \\
\text { plans }\end{array}$ & 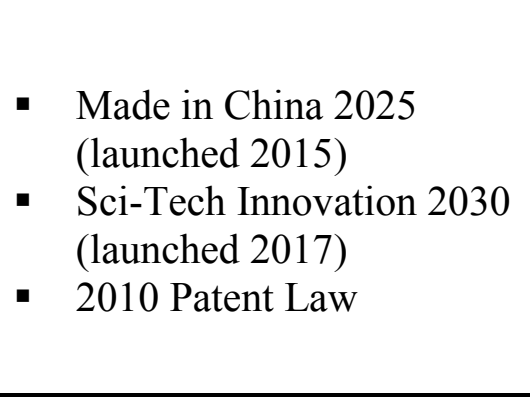 & $\begin{array}{l}\text { - S\&T Development Plan } \\
\text { for 2011-2020 (launched } \\
\text { 2010) } \\
\text { - Vietnam Silicon Valley } \\
\text { Project (launched 2013) } \\
\text { - S\&T Plan 2016-20 } \\
\text { - Project 844 (launched } \\
\text { 2016) }\end{array}$ \\
\hline S\&T Missions & $\begin{array}{l}\text { - Innovation nation by } \\
2020 \\
\text { - International leader in } \\
\text { innovation by } 2030 \\
\text { - World Powerhouse in } \\
\text { scientific and } \\
\text { technological innovation } \\
\text { by } 2050\end{array}$ & $\begin{array}{l}\text { Reach level of S\&T } \\
\text { performance of advanced } \\
\text { ASEAN peers by } 2020 \\
\text { - } \text { High-tech products to } \\
\text { account for } 45 \text { per cent of } \\
\text { exports by } 2020 \\
\text { - 5,000 SMEs and } 30 \\
\text { incubators by } 2020\end{array}$ \\
\hline \multicolumn{3}{|l|}{ Invention-oriented Policy } \\
\hline $\begin{array}{l}\text { Gross expenditure on } R \& D \\
\text { (GERD) (per cent) }\end{array}$ & $\begin{array}{l}2.07(2015) ; \text { tripled between } \\
1995 \text { and } 2012\end{array}$ & $\begin{array}{l}0.4(2015) \text {; increased from } \\
0.2 \text { per cent in } 2002\end{array}$ \\
\hline $\begin{array}{l}\text { Target GERD (per cent by } \\
2020 \text { ) }\end{array}$ & 2.5 & 1.5 \\
\hline $\begin{array}{l}\text { Tax incentives for } R \& D \\
\text { expenditure by private } \\
\text { firms }\end{array}$ & $\begin{array}{l}50 \text { per cent tax relief for large } \\
\text { enterprises; } 75 \text { per cent for } \\
\text { SMEs }\end{array}$ & $\begin{array}{l}\text { Enterprises can appropriate } \\
\text { up to } 10 \text { per cent of annual } \\
\text { profits to a tax deductible } \\
\text { R\&D fund }\end{array}$ \\
\hline \multicolumn{3}{|l|}{ National Innovation System } \\
\hline $\begin{array}{l}\text { S\&T Expenditure (as \% of } \\
\text { state budget) }\end{array}$ & $3.6(2017)$ & 0.77 (2017 est) \\
\hline Funds & $\begin{array}{l}\text { Innovation Fund for Small } \\
\text { Technology-based Firms } \\
\text { (InnoFund) (1999) }\end{array}$ & $\begin{array}{l}\text { National Technology } \\
\text { Innovation Fund (2015) }\end{array}$ \\
\hline Policymaking bodies & $\begin{array}{l}\text { MoST, Ministry of Industry } \\
\text { and Information Technology, } \\
\text { State Steering Committee of } \\
\text { Science and Technology and } \\
\text { Education }\end{array}$ & $\begin{array}{l}\text { MoST, MPI, NAFOSTED, } \\
\text { NATEC }\end{array}$ \\
\hline
\end{tabular}

Sources: Authors' analysis based upon Fuller (2013, 2016); Witt and Redding (2013);

Klingler-Vidra (2014b); CIEM et al (2015); Child (2016); China Daily (2017); Lewin, Kenney \& Murmann (2016); World Bank \& MPI (2016); Phan, Tu \& Boggert (2017); UNESCO Institute for Statistics (2016; 2018); General Statistics Office (2018). 
In short, the government aims to advance Vietnam's technology sector by 'encouraging both domestic and international entrepreneurs' to start businesses in its growing entrepreneurial ecosystem, within and beyond its growing science parks (Marvin, 2016). Two prongs of the Chinese S\&T policy advance are either missing or insufficient in Vietnam: nationally concerned missions to move Vietnam closer to the world frontier in selected sectors; and public funding for R\&D to bolster indigenous invention capacity across-the-board. With these elements missing, the growing number of startups are not advancing much in their technical capability.

\section{Vietnam's S\&T policy context: multinationals, firm capabilities and returnees}

Well before Vietnam reached lower middle income status, government and business were talking of making Vietnam into a high-tech hub. Enthusiasm for tech investment soared when Intel, the world's leading chip maker, opened a $\$ 1$ billion facility in 2010 - its largest globally outside of Ho Chi Minh City. The spectacular coup of the Intel plant seemed to say that the sky was the limit for S\&T in Vietnam.

Intel decided to invest in Vietnam as it scaled down testing and assembly in its China facility, for reasons of rising costs and fear of intellectual property theft. It chose Vietnam thanks to the efforts of a returnee who had worked at Intel's Santa Clara headquarters for fifteen years, and then lobbied top management to agree to the investment, under his management (KlinglerVidra, 2014b). Intel came at its own initiative, without much courting by government. Following negotiations with the mayors of Hanoi and Ho Chi Minh City over incentive packages - a race to get maximum subsidy - the semiconductor giant committed to establish the plant focused on 
testing and assembly in the Saigon Hi-Tech Park, a science park forty-five minutes outside of Ho Chi Minh City (personal communication, August 24, 2012).

The Intel plant represented a significant anchor for S\&T in Vietnam. Upon its opening, Intel announced it would send top local students to complete a study exchange in electrical engineering at Portland State University in the United States (personal communication, August 24, 2012). Headlines in western media proclaimed that Intel put 'Vietnam on global tech map' (Boudreau, 2010) and called the Socialist Republic the 'new Asian hotspot for top hi-tech manufactures' (Van Marle, 2015). More recently, excitement about Vietnam as a high-tech centre came in 2012 when IBM selected Da Nang as one of the 33 cities that it would choose, globally, for its $\$ 50$ million Smarter Cities Challenge grant - this came nearly 20 years after IBM established offices in Hanoi and Ho Chi Minh City.

Just as Intel's choice of the Saigon Hi-Tech Park was steered by a high performing returnee from Silicon Valley, other Vietnamese with experience in the Valley have returned to set up local operations. One such example is Hung Q. Nguyen, who studied in the U.S. before establishing a tech startup in Silicon Valley in 1994. As the company (LogiGear) grew and considered international outsourcing locations, in 2005 Nguyen chose to set up an R\&D centre in Ho Chi Minh City (Marvin, 2016). Ten years later, LogiGear had more than 500 employees and a second facility in Da Nang. Another high-profile returnee is the managing director of a leading venture capital firm in Vietnam, Henry B. Nguyen of IDG Ventures Vietnam, whose family fled Vietnam for the United States shortly after he was born. Henry completed his BA at Harvard University, earned his MD and MBA from Northwestern University, and was an Associate at Goldman Sachs in New York before moving to Vietnam in 2001 (Klingler-Vidra, 2014b). Nguyen is the son-in-law of Nguyễn Tấn Dũng, the Prime Minister of Vietnam from 2006 to 
2016. He represents a venture capital manager coming into close proximity with the head of the Vietnamese state.

The Silicon Valley returnees - along with the broader growth of technology MNCs producing in Vietnam, including Cisco, HP, Intel, Fujitsu, LG, Samsung, Sony, Toshiba and Ericsson- have propelled the number of firms operating in hardware, software, and digital content to nearly 14,000 by 2016 (Marvin, 2016; Akhaya, 2018). The founder of Vietnam's first unicorn, $\mathrm{VNG}$, is a much-admired returnee who studied finance in Australia before returning to found the gaming company in 2004 . The number of startups - founded by returnees amongst others - has grown fast (Bathke, 2018). In 2017, Vietnamese startups received investments worth \$291 million, which represents a 42 per cent increase over 2016 (Das 2018), and the number of venture capital investment deals grew from 10 in 2011 up to 92 in 2017 (Nguyen, 2017).

But now come the qualifications to this 'success' story. Analysts find that 'the majority of these high-tech exports were designed elsewhere and simply assembled in [Viet Nam]' (UNESCO, 2016). From an innovation capability perspective, this does not reflect an advance of indigenous innovation capacity. Le, Pham, Ho \& Tran (2016, p. 35) say, 'instead of investing in technology and knowledge, [Vietnamese enterprises still] mainly rely on the advantages of cheap labour and raw materials exploitation'. The so-called high-tech firms remain small and compete internationally almost entirely on cost, not innovation or quality (Fannin, 2011; Nguyen, 2015).

In the Technology and Competitiveness Survey on Vietnam - developed and managed through a partnership of Vietnam's Central Institute for Economic Management (CIEM), the General Statistics Office, and the Development Economic Research Group of the Department of Economics at the University of Copenhagen - the authors argue that in order to 'transition from relying on "factor-accumulation" to a "TFP" [total factor productivity]-driven economy' the 
Socialist Republic needs to increase focus 'on productivity and technology' (2014, p. 5). The survey found that only 13.5 per cent of SMEs were conducting 'innovation activities', which includes original $\mathrm{R} \& \mathrm{D}$ and adoption of outside technologies, and only 0.6 per cent of firms surveyed were developing a new product (Hue, 2017, p. 2).

With limited access to external funding and with little government help to buffer them from global market forces, they have not been able to adequately invest in $R \& D$ to enter more complex value-added processes (Do, 2016). Vietnam boasts an array of public research institutes, but unlike their Taiwanese and South Korean counterparts from the 1970s onwards, they have no strong incentives to collaborate with private enterprises (Wade, 2004). Conversely, Vietnamese enterprises experience difficulty in making partnerships to develop joint research activities or production innovation with public research institutions (Ca, 2006).

The result is that the distribution of firms displays a 'missing middle' (Hakkala \& Kokko, 2007). Foreign-invested firms dominate exports, while few domestic firms have invested in the capacity to innovate to the point where they can compete internationally, even with low labour costs (Nguyen, 2016). Whilst there are FDI spillovers, they are not through direct linkages between domestic and foreign firms. The firm learning occurs through strong intra-firm, or 'forward' technology transfer, in which local firms in long-term contracts with foreign multinationals provide their 'domestic input suppliers with technological know-how about how to produce new inputs' and employees acquire skills while working for the foreign firms (CIEM, GSO \& Department of Economics, 2015). The limited knowledge transfer from MNCs to domestic SMEs contributes to the persistence of a bifurcation in capabilities - and activities which is sometimes called a 'Two-Speed Economy'. Ericsson's November 2018 announcement of a new Innovation Hub, to be based in the Hoa Lac Hi-Tech Park, typifies the ecosystem, not 
deep tech, aims of the MNC-government partnership in Vietnam: 'bringing MoST and entrepreneurs, businesses as well as universities together into an ecosystem' (Akhaya, 2018).

An external assessment comes from the Global Entrepreneurship Monitor (GEM) (2016, p. 11), a publication by Babson College and London Business School comparing national entrepreneurial activities for more than 50 countries since 1999. It says, flatly, 'entrepreneurial activities in Vietnam mainly are not innovative'. According to GEM's innovation indicator in 2017-18, Vietnam ranked $48^{\text {th }}$ (out of 54 countries globally), while Thailand and Malaysia tied for $15^{\text {th }}$. Yet on GEM's ranking by 'entrepreneurial spirit', it comes $15^{\text {th }}$, ahead of both Malaysia $\left(28^{\text {th }}\right)$ and Thailand $\left(30^{\text {th }}\right)$. These two rankings substantiate the combination of Vietnam's rising number of startups and little capacity for innovation.

\section{Explaining the gap between China-inspired S\&T policy and Silicon Valley-inspired ecosystem support}

The 'market-opening plus subsidy' strategy that ushered in foreign ICT firms to set up assembly and testing facilities - as in the case of Intel and IBM - is not, on its own, likely to drive advances in the capabilities of other firms producing in Vietnam. So why has it remained the central thrust of the government's technology strategy, with little being done to boost more targeted public S\&T investment?

Interviews with policymakers point to two explanations. First, ministerial coordination issues fundamentally inhibit the Ministry of Science and Technology's ability to pursue a grand S\&T strategy: in Vietnam's decentralised context, it relies on other ministries, particularly the Ministry of Planning and Investment (MPI), in order to function. The MoST's lack of 
institutional power is said to result from 'the nature of investing in S\&T: there's no opportunity for cash kickbacks to other government officials in S\&T. In construction, for example, there's lots of physical cash to hand out, so big budget is given' (personal communication, November 29, 2018). The informant went on to explain that 'unlike America, S\&T has not yet made a big impact on the economy, so it's tough to get money for it.' In addition to the small budget to begin with, MoST then struggles to spend its funds due to a process whereby the MPI and Ministry of Finance (MoF) act as purse-holders. As one interviewee confided, her programme was not materialising because MoST 'were afraid of [the] MoF criticising them for using the state budget'. She remarked that whilst 'MoST [is] in charge of overall strategy, [the] MoF [is] in charge of budget and the MPI is in charge of capital investment. The MoST send[s] budget plans to MPI for coordinating and MoF for consolidation and disbursement' (personal communication, 27 October 2016). A manager for startup development at the MoST's National Agency for Technology Entrepreneurship and Commercialisation Development similarly remarked that 'we [have] spread out resources. We don't get a big chunk of resources. It's very thin.' (personal communication, October 14, 2016).

The MoST has primary responsibility for coordinating across 'ministries, ministerial-level, government-attached agencies, provincial-level People's Committees and other state agencies' in order to elaborate and submit master S\&T plans to the Prime Minister. Such national S\&T policymakers set vague declarations, and then provincial entities, but then sub-national Departments of Science and Technology, are given budget directly from the Prime Minister and are then themselves responsible for designing and implementing their local initiatives (OECD/World Bank, 2014, p. 33; personal communication, October 27, 2016). This brand of decentralisation is said to cause 'multiple and partly competing strategies, as well as overlapping 
and weak' implementation (OECD/World Bank, 2014, p. 26). In the words of one informant, NATEC, which advises the MPI, MoF, Prime Minister's office, provincial level organisations as well as the MoST, works with 'whoever can have an impact' at that time. More than a difficulty in making policy and getting budgetary approval, the coordination issues also cause delays in implementation. As a vivid example, a manager in the MPI's Agency for SME Development explained, 'MoST’s Science and Technology Fund was approved in 2003 but was actually launched in 2008 - a five-year delay’ (personal communication, August 21, 2012).

These challenges undermining S\&T policy are akin to what Vietnam scholars such as Kenichi Ohno (2009) have stressed elsewhere, that policy-making capabilities are handicapped by weak inter-ministerial coordination. Masina (2010, p. 4) says the state lacks 'the kind of state capacity required to implement a coherent set of developmental state policies'. Indeed, the pursuit of ecosystem-promotion is consistent with broader assessments of Vietnam as an 'ad hoc' and 'incoherent' developmental state (Malesky \& London, 2014). London (2013) coins the phrase 'chaebol dreaming' to capture the gap between the purported aim of Vietnamese industrial policy and the uncoordinated reality.

Given the budgetary constraints, MoST policymakers are highly receptive to proposals for activities that require small sums. Our informants explained that this preference for light-touch funding proposals translates into interpreting China's S\&T policy model in a way that is relevant to them. Our NATEC interviewee asserted that 'we learn[ed] a lot from China. In 2011, China was doing a lot, and the Vietnamese MoST ministers noticed it. But the elements that we [NATEC] took up as foundations are building technology exchanges regionally, either online or physical platforms.' They emphasised the promotion of exchanges and platforms, not the marked increase in R\&D or broader growth in the S\&T budget. The hefty spending, they knew, would be 
difficult for them, so they focused on adapting the smaller ticket items. They valued policies which involved a small budget but which also seemed to deliver elements of revered models.

This brings us to the second causal mechanism. The MoST's preference for exchangefocused policies requiring only a modest budget was met, following the Global Financial Crisis, with an in-flood of returnees experienced in the technology sector in the United States (Peel, 2015). In the case of the MoST supporting the Vietnam Silicon Valley Project, an interviewee revealed that a 'private sector person comes in and lobbies the ministry in 2013. She had learned from Y-Combinator and TechStars, as she went abroad, to America, with delegations and then came back and said 'why don't we have productive innovators in Vietnam?' (personal communication, October 14, 2016). After agreeing with MoST that Vietnam should 'import the programme from Y Combinator and tweaked it here and there to make it suitable for the Vietnam environment' the MoST was still unable to fund the effort (personal communication, November $29,2018)$. Instead, she used her personal wealth to fund the first year's operations, and only in the second year (2014) did the MoST give "match funding and free office space as in-kind support' (personal communication, November 29, 2018). Vietnam Silicon Valley's two office spaces - in Hanoi and Ho Chi Minh City - are free spaces provided by the MoST. All they need to do is to 'pay for the electricity.' The MoST's proclivity for offering space instead of finance capital was reiterated in another interview, as 'when [MoST] contributes to projects they increase the valuation of land donated, so that it looks like they are contributing more financially' (personal communication, August 23, 2012).

Returnees proposed ecosystem building policies, they have established startups, and have brought high-tech MNCs to the market. A prominent group of returnees call themselves the 'MIT 5' and are MIT graduates who returned to Vietnam in 2013 and 2014 'to make a 
difference'. They organise talks around the country, and consult with the government on how to bring in the Silicon Valley model (personal communication, November 29, 2018). They are also revered as role models for entrepreneurship, as one of the five is the Chief Technology Officer at one of Southeast Asia's first unicorns. Successful Vietnamese entrepreneurs such as the CEO of VNG and the MIT 5 are acting as 'roles models for Vietnam, just as Steve Jobs and Bill Gates did for America' (personal communication, November 28, 2018).

Finally, both of these mechanisms are reinforced by an additional factor. Vietnam's large aid donor community has been overwhelmingly supportive of the startup market-building efforts. Former World Bank Vietnam country director, Victoria Kwakwa, explained that the role of the government was 'to adopt clear, stable and business friendly regulations and policies, and facilitate better access to financing by enterprises' - without any sectoral targeting (OECD/World Bank, 2014). If we 'follow the money' to ascertain what activities donor advice has incentivised since 2009, we find that in 2013 the World Bank entered a partnership with the MoST, for the first time ever, to mount the aptly named FIRST project - Fostering Innovation through Research, Science and Technology (FIRST). The World Bank committed to lend \$100 million on FIRST in order to: 'support science, technology and innovation in Vietnam by designing and piloting STI policies' and by 'encouraging the development of innovative technology enterprises' (World Bank, 2013, p. 1). Consistent with the larger pattern, FIRST aims to help the government implement across-the-board S\&T strategies to encourage ecosystem development, rather than formulate more targeted sectoral objectives.

\section{Conclusion}


In principle, everyone agrees: Vietnamese policymakers and their donor community say that they support a big push on science and technology, and have frequently invoked the fear of the middle income trap as justification for doing so ever since 2010. The government has multiplied the number and remit of organisations responsible for S\&T policy. Yet almost a decade later, the policy remains without articulated missions and without an increase in public investment. The major but vague thrust is to build a Silicon Valley-like entrepreneurial ecosystem, and the capabilities to be advanced are, implicitly, those of entrepreneurship (getting firms up and running) as opposed to technical innovation.

In this respect, Vietnam is hardly alone. Paus (2014, p. 50) says that 'in many countries industrial policies have been piece-meal and not part of overall strategic focus on the advancement of technological capabilities'. But several major developed countries - notably the US, Germany and Japan - have high octane policies to incentivise R\&D both across-the-board and in specific technologies; and China is a dramatic case among developing countries. Vietnam's S\&T policy neglects this experience; and in particular, neglects the substantial public invention-promotion underpinning the historical advance of Silicon Valley in the US, even as the US government has long declared neoliberalism to be its ideology (see Mazzucato, 2013; Weiss, 2014; Wade, 2017; Klingler-Vidra, 2018).

While the policymakers say they wish to emulate both Silicon Valley and China's Made in China 2025, and invoke the middle income trap as particular justification, in practice they tend to do little more than partner with initiatives aimed at making it easier to establish startups. A lack of commitment to mission-oriented, well-funded S\&T policy stems from a confluence of domestic factors, particularly the MoST's relative weakness to other ministries combined with an influx of US-trained returnees proselytising Silicon Valley-styled policies. This ecosystem- 
building orientation is well-received and reinforced by international donors who themselves implement strategies in the form of ecosystem-promotion efforts a la the Vietnam-Finland Innovation Partnership Programme and the World Bank's FIRST initiative.

Today's concurrent trends of production being organised in global value chains, knowledge monopoly (by firms based in advanced economies), financialisation, and the asymmetric adjustment pressure on deficit countries, together mean that developing countries are unlikely to converge with advanced economies in productivity levels through 'the power of the market' (Paus, 2012; Wade, 2018). Concerted state action to impart directional thrust to investment - including by expanding the capacity to absorb technology from elsewhere and innovate at home - is an (almost) necessary condition for sustained fast growth (Noman \& Stiglitz, 2016). Non-directional S\&T policy will likely hold back 'catch up', as Silicon Valleyinspired startup ecosystem promotion comes without increased investment in the technical capabilities which underpin similar efforts in China. This leaves startups destined to remain as imitators and assemblers, and posing a question mark about the economy's prospects for sustained growth through the middle income range. 


\section{References}

Akhaya, Prisca T. (2018) Vietnam inks agreement with Ericsson to open IoT Innovation Hub. e27, November 30. Retrieved from www.e27.co.

Autio, E. \& H. Rannikko. (2016). Retaining winners: Can policy boost high-growth entrepreneurship? Research Policy, 45(1), 42-55.

Bathke, Benjamin. (2018). Returning Vietnamese are leaving their mark on Vietnam's burgeoning startup scene. Tech in Asia, June 27. Retrieved from www.techinasia.com.

Boudreau, J. (2010). Intel puts Vietnam on global tech map. The Bulletin, November 7.

Breznitz, D., D. Ornston \& S. Samford. (2018). Mission critical: the ends, means, and design of innovation agencies. Industrial and Corporate Change, 5(1), 883-896.

Ca, T.N. (2006). Universities as Drivers of the Urban Economies in Asia: The Case of Vietnam, World Bank Policy Research Working Paper Series 3949, June.

Cheong, K-C., P.M. Duc, \& T. Nguyen. (2010). From low-income to industrialised: Vietnam in the next decade and beyond. Washington, DC: World Bank.

CIEM (Central Institute for Economic Management), the General Statistics Office (GSO) and the Department of Economics at the University of Copenhagen. (2015) Firm-level Technology and Competitiveness in Vietnam: Evidence from 2010-2014 Surveys. April. Hanoi, Vietnam.

Child, J. (2016) Building the innovative capacity of SMEs in China. In A.Y. Lewin, M. Kenney \& J.P. Murmann (Eds.), China's Innovation Challenge: Overcoming the Middle-Income Trap (pp. 189-218). Cambridge, UK: Cambridge University Press.

Collinson, S.S. (2016). Who benefits when MNEs partner with local enterprises in China? In A.Y. Lewin, M. Kenney \& J.P. Murmann (Eds.), China's Innovation Challenge: Overcoming the Middle-Income Trap (pp. 219-247). Cambridge, UK: Cambridge University Press.

Das, K. (2018). Startup Ecosystem in Vietnam. Vietnam Briefing, 8 June.

Do, A-M. (2016). What's Keeping Vietnam's Startups from Scaling Up? Forbes, 8 November. Retrieved from www.forbes.com.

Doner, R.R. \& B.R. Schneider. (2016). The Middle-Income Trap: More Politics than Economics. World Politics, 68(4), 608-44.

Edler, J. \& J. Fagerberg. (2017). Innovation policy: what, why and how, Oxford Review of Economic Policy, 33(1), 2-23.

Ergas, H. (1986). Does technology policy matter? in BR Guile, H. Brooks (Eds.) Technology and Global Industry: Companies and Nations in the World Economy, Washington, DC: National Academy Press.

Fuller, D.B. (2010). (Ed.), Innovation Policy and the Limits of Laissez-faire: Hong Kong's Policy in Comparative Perspective. New York, NY: Palgrave MacMillan.

Fuller, D.B. (2013). Building ladders out of chains: China's hybrid-led technological development in disaggregated value chains. Journal of Development Studies, 49(4), 547563.

Fuller, D.B. (2016). China's political economy: Prospects for technological innovation-based growth. In A.Y. Lewin, M. Kenney \& J.P. Murmann (Eds.), China's Innovation Challenge: Overcoming the Middle-Income Trap (pp. 121-151). Cambridge: Cambridge University Press.

Gill, I. \& H. Kharas. (2007) An East Asian Renaissance: Ideas for Economic Growth. Washington, DC: World Bank.

Vietnam's S\&T policy and the middle income trap 
GEM (Global Entrepreneurship Monitor). (2016). Global Entrepreneurship Monitor Vietnam 2015/16.

GSO \& CIEM. (2014). Technology and Competitiveness in Vietnam Survey. Hanoi, VN: GSO.

Hall, B.H., (2002). The financing of research and development. Oxford Review of Economic Policy, 18(1), 35-51.

Hue, T.T. (2017, August). Proceedings of the International Academic Research Conference on Small \& Medium Enterprises (SMEs), Hanoi, VN.

Hung, H.S. (2011, May). Project Detailed Outline Project: Vietnam - Inclusive Innovation. Ministry of Planning \& Investment Enterprise Development Agency. Hanoi, VN.

International Monetary Fund (IMF). (2016). Chapter 2: Fiscal Policies for Innovation and Growth. April. Washington, DC: IMF.

Klingler-Vidra, R. (2014a). The Public Venture Policy Menu: Policies Public Authorities Can Take. Coller Venture Review, 1a, 36-43.

Klingler-Vidra, R. (2014b). Building a Venture Capital Market in Vietnam: Diffusion of a Neoliberal Market Strategy to a Socialist State. Asian Studies Review, 38(4), 582-600.

Klingler-Vidra, R. (2018). The Venture Capital State: The Silicon Valley Model in East Asia. Ithaca, NY: Cornell University Press.

Le, T.T.H., P.T. Linh, H.T.T. Quynh \& T.T.K. Chi. (2016). The Relationship between Innovation Capabilities and Efficiency of Foreign Invested Enterprises in Vietnam. $V N U$ Journal of Science: Policy and Management Studies, 31(2), 34-50.

Lee, Kai-Fu. (2018). AI Superpowers: China, Silicon Valley and the New World Order. Houghton Mufflin.

Lerner, J. (2009). Boulevard of Broken Dreams: Why Public Efforts to Boost Entrepreneurship and Venture Capital Have Failed - and What to Do About It. Princeton: Princeton University Press.

Lewin, A.Y., M. Kenney \& J.P. Murmann. (2016). China's innovation challenge: An introduction. In A.Y. Lewin, M. Kenney \& J.P. Murmann (Eds.), China's Innovation Challenge: Overcoming the Middle-Income Trap (pp. 1-31). Cambridge: Cambridge University Press.

London, J. (2013). Welfare regimes in China and Viet Nam. Journal of Contemporary Asia, 44, 84-107.

Lundvall, B-A. (1992). National Systems of Innovation: Towards a Theory of Innovation and Interactive Learning, London: Pinter.

Malesky, E. \& J. London. (2014). The Political Economy of Development in China and Vietnam. Annual Review of Political Science, 17, 395-419.

Marvin, R. (2016). Vietnam's Tech Boom: A look inside Southeast Asia's Silicon Valley, PC Magazine. 23 June. Retrieved from www.pcmag.com.

Masina, P. (2010). Vietnam between developmental state and neoliberalism: the case of the industrial sector, cMET Working paper 7/2010. December.

Mazzucato, M. (2013). The Entrepreneurial State. London: Anthem Press.

Mazzucato, M. (2018). Mission-oriented innovation policy and dynamic capabilities in the public sector. Industrial and Corporate Change, 5(1), 803-815.

Mishra, D. (2011). Vietnam development report 2012 : market economy for a middle-income Vietnam. Washington DC: The World Bank. 
Ministry of Finance (China). (2018) Report on the Execution of the Central and Local Budgets for 2017 and on the Draft Central and Local Budgets for 2018. First Session of the $13^{\text {th }}$ National People's Congress of the People's Republic of China, March 15, 2018.

MPI AED (Ministry of Planning and Investment Agency for Enterprise Development). (2016) Startup Policies Direction in Vietnam. Hanoi, VN.

MoST (Ministry of Science and Technology). (2015). Key Directions, Objectives and Tasks of Science and Technology for the 2016-2020 Period No. 1318/QD-BKHCN. 23 June.

MoST. (2014). Vietnam's Science and Technology 2014. Hanoi: Science and Technics Publishing House.

Nee, V. \& S. Opper. (2012). Capitalism from Below: Markets and Institutional Change in China. Cambridge, MA: Harvard University Press.

Nelson, R.R. (1988). Institutions Supporting Technical Change in the United States. In G. Dosi, C. Freeman, R. Nelson, G. Silverberg \& L. Soete (Eds.), Technical Change and Economic Theory (pp. 312-329). London: Pinter.

Niosi, J. (2008). Technology, Development and Innovation Systems: An Introduction. Journal of Development Studies, 44(5), 613-621.

Nguyen, D.T.U. (2015). Vietnam Growth Masks Weak Local Firms in 2-Speed Eonomy. Bloomberg, 8 November. Retrieved from www.bloomberg.com.

Nguyen, T.B.N. (2016). Vietnam working on policy push to build VC ecosystem to fund tech startups. Deal Street Asia, 19 January. Retrieved from www.dealstreetasia.com.

Nguyen, V.T. \& N.J. Freeman. (2009). State-owned enterprises in Vietnam: Are they 'crowding out' the private sector? Post-Communist Economies, 21, 227-47.

Nguyen, D. (2018). Investment in Vietnamese startups booming, VN Express International, May 25. Retrieved from https://e.vnexpress.net.

Noman, A. \& J.E. Stiglitz. (2016). Learning, Industrial and Technology Policies. In A. Noman \& J.E. Stiglitz (Eds.), Efficiency, Finance and Varieties of Industrial Policy: Guiding Resources, Learning and Technology for Sustained Growth (pp. 1-20). New York, NY: Columbia University Press.

OECD. (1997). National Innovation Systems, Paris: OECD.

OECD (2007). Innovation and Growth: Rationale for Innovation Strategy, Paris: OECD.

OECD. (2011). OECD Review of Innovation in Southeast Asia: Country Profile of Innovation: Vietnam. OECD Directorate for Science, Technology and Industry. Paris: OECD.

OECD/The World Bank. (2014). Science, Technology and Innovation in Vietnam. Paris: OECD.

Ohno, K. (2009). Avoiding the Middle Income Trap: Renovating Industrial Policy Formulation in Vietnam. ASEAN Economic Bulletin, 26 (1), 25-43.

Painter, M. (2005). The Politics of State Sector Reforms in Vietnam: Contested Agendas an Uncertain Trajectories. Journal of Development Studies, 41(2), 261-83.

Paus, E. (2012). Confronting the Middle Income Trap: Insights from Small Latecomers. Studies in Comparative International Devevelopment, 47, 115-138.

Paus, E. (2014). Latin America and the middle-income trap, United National ECLAC Financing for Development.

Peel, Michal. 2015. Vietnam: Profitable Return. Financial Times, 19 April. Retrieved from www.ft.com.

Phan, L., H. Tu \& T. Borgert. (2017, April). Vietnam's startup policy: a policy learning perspective. Paper presented at the Entrepreneurship and Smart Cities Symposium at Lingnan University, Hong Kong.

Vietnam's S\&T policy and the middle income trap 
Schumpeter, J. (1934). The Theory of Economic Development. Cambridge, MA: Harvard University Press.

Tuoi Tre News. (2016). Intel Vietnam to lay off sales head, two-thirds of employees in massive restructure. Tuoi Tre News, 29 September.

UNESCO. (2016). ASEAN Economic Community likely to spur scientific co-operation.

Van Marle, R. (2015). Vietnam fast becoming the new Asian hotspot for top hi-tech manufacturers. Load Star, 5 May.

VietnamNet. (2014). How much does Vietnam spend on agricultural research? 31 December.

Vu, X., N. Hong \& Hoang V.C. (2010, May). Restructuring Technological Innovation Activities in Vietnam: Sub-component of the Project Restructuring the economy. Hanoi: Ministry of Planning \& Investment.

Wade, R. H. (2004) Governing the Market: Economic Theory and the Role of Government in East Asian Industrialization. Princeton, NJ: Princeton University Press.

Wade, R. H. (2016). Industrial policy in response to the middle-income trap and the Third Wave of the digital revolution. Global Policy, 7(4), 469-480.

Wade, R. H. (2017) "The American paradox: ideology of free markets and the hidden practice of directional thrust", Cambridge Journal of Economics, 41(3): 859-880.

Wade, R. H. (2018). Developmental State: Dead or Alive? Development and Change, 49(2), 518-546.

Warwick, K. \& Nolan, A. (2014). Evaluation of industrial policy: methodological issues and policy lessons. Paris: OECD.

Weiss, L. (2014). America Inc.? Innovation and Enterprise in the National Security State, Ithaca, NY: Cornell University Press.

World Bank. (2011). Market Economy for a Middle-Income Vietnam: Joint Donor Report to the Vietnamese Consultative Group, Washington, DC: World Bank.

World Bank. (2012). Vietnam-World Bank: Long-Term Companions in Development. Washington, DC: World Bank.

World Bank. (2013). Vietnam: Achieving Success as a Middle-income Country. Washington, DC: World Bank.

World Bank \& Ministry of Planning and Investment of Vietnam. (2016). Vietnam 2035: Toward Prosperity, Creativity, Equity, and Democracy. Hanoi: World Bank Vietnam.

World Bank. (2017). Vietnam Public Expenditure Review: Summary Report (English). Washington, DC: World Bank.

Yeo, Y. \& Painter, M. (2011). Diffusion, transmutation, and regulatory regime in socialist market economies: Telecoms reform in China and Vietnam. Pacific Review, 24(4), 375395.

Vietnam's S\&T policy and the middle income trap 